Page: 529-535 ISBN: 978-602-6 988-75-1

Web Jurnal Online: jurnal.unmuhjember.ac.id

By: Asep Nurwanda; Regi Refian Garis

Analysis Of Performance Appraisal, Talent, Performance Of State Civil Apparatus In Realizing Good Government Governance (Analysis Study On Bkdd Of Ciamis Regency)

\title{
ANALYSIS OF PERFORMANCE APPRAISAL, TALENT, PERFORMANCE OF STATE CIVIL APPARATUS IN REALIZING GOOD GOVERNMENT GOVERNANCE (ANALYSIS STUDY ON BKDD OF CIAMIS REGENCY)
}

\author{
Asep Nurwanda, Regi Refian Garis \\ Universitas Galuh \\ Email: asepnurwanda@gmail.com
}

\begin{abstract}
Good governance also means that governance is carried out in an effective and efficient manner by developing performance. So far the performance program of Civil Servants is still centralized so that the potentials of local wisdom and local culture have not been able to be developed. Performance appraisal and talent are integrated parts of a performance. The present performance evaluation of Civil Servants still uses DP3 (List of Job Implementation Assessments) which still raises doubts in accurately describing the performance of Civil Servants, DP3 is also considered to be less flexible to express things that are special characters that distinguish a profession from profession others and are vulnerable to subjectivity, DP3 assessment results are never discussed or evaluated together to get feedback from employees. DP3 has not been able to meet the employee performance evaluation criteria that compare the results of the implementation of tasks with the standards set. The purpose of this research is to provide an overview of the Performance Appraisal Optimization, Talent of Civil Servants and Performance in an effort to realize Good Government Governance on the BKDD of Ciamis Regency. Performance Assessment is a formal process carried out by leaders in the organization to measure traits related to the performance or work performance and behavior of subordinates. The performance and behavior of employees are compared to the anchors set by the organization or with the company's goals talent is a goal-oriented and integrated process in planning, withdrawing, developing, managing and providing employee compensation. The Performance is a process that consolidates goal setting, performance appraisal, and development into a system whose purpose is to ensure that employee performance supports the company's strategic goals. The implementation of performance, talent and performance assessments so far has not been able to realize Good Government Governance, this is reflected in the role of Civil Servants in implementing public services who still place themselves as bureaucrats, not as public servants.
\end{abstract}

Keywords: Performance Appraisal, Performance, Talent, Good Government Governance. 
Proceeding ICOGISS 2019

Page: 529-535 ISBN: 978-602-6 988-75-1

Web Jurnal Online: jurnal.unmuhjember.ac.id

By: Asep Nurwanda; Regi Refian Garis

Analysis Of Performance Appraisal, Talent, Performance Of State Civil Apparatus In Realizing Good Government Governance (Analysis Study On Bkdd Of Ciamis Regency)

\section{INTRODUCTION}

Good governance also means that the government is implemented effectively and efficiently. Effective means that programs planned and implemented are on target and provide direct benefits. Efficient means that every government administration program planned by the government really provides the right benefits as planned. The measure of accuracy with the goals or objectives and useful for the community is a manifestation of the performance (performance) of Civil Servants because performance is a means through which superiors ensure that the activities and output of employees are the same as the goals of agencies/organizations. So far the performance program of Civil Servants is still centralized so that the potentials of local wisdom and local culture have not been able to be developed. Performance appraisal and talent are integrated parts of a performance.

The performance appraisal of Civil Servants currently still uses DP3 (List of Job Implementation Assessments) which still raises doubts in accurately describing the performance of the Civil Servants. DP3 is also considered to be less flexible to express things that are special characteristics that distinguish a profession from other professions and are vulnerable to subjectivity. Moreover, the results of these assessments have never been discussed or evaluated together to get feedback from employees. In the assessment of employee performance, it will also compare the results of the implementation of tasks with the standards that have been set, again the DP3 has not been able to meet these criteria. Performance appraisal can also measure talent and employees in an effort to achieve the performance of Civil Servants. From the results of the performance appraisal, feedback will be generated which will improve talent and performance continuously which will ultimately improve government performance.

From the above problems the authors are interested in choosing the research title; Analysis of Performance Appraisal of Civil Servant Talent and Performance in realizing Good Government Governance.

\section{THEORETICAL STUDY}

\section{a. Performance Appraisal}

The terms performance appraisal and performance evaluation (performance evaluation) are often used interchangeably for the same purpose, below are presented an understanding of the performance of experts.Understanding performance appraisal according to experts as follows: According to Dessler (2013:310) "Performance appraisal process means evaluates an employ's current and/or past performance relative to his or her performance standards." Performance appraisal implies a process of evaluating employee performance produced compared to the standard set.

According to Noe. et al. (2008: 343) "Performance Appraisal process through an organization on how well employ is doing his or her job." Performance appraisal is where an organization performs a process of assessing how well an employee does his job.

From the above definitions, it can be concluded that Performance Evaluation is a formal process carried out by leaders in the organization to measure characteristics related to the performance or work performance and behavior of subordinates. The 
Proceeding ICOGISS 2019

Page: 529-535 ISBN: 978-602-6 988-75-1

Web Jurnal Online: jurnal.unmuhjember.ac.id

By: Asep Nurwanda; Regi Refian Garis

Analysis Of Performance Appraisal, Talent, Performance Of State Civil Apparatus In Realizing Good Government Governance (Analysis Study On Bkdd Of Ciamis Regency)

performance and behavior of employees are compared to the anchors set by the organization or with the goals of the organization. In performance appraisal, a measure must be established that will provide justice to all employees assessed. It is expected that through the measure of work results or standardized performance it can motivate and improve employee performance or create feedback.

Mangkunegara (2007: 19) that "the purpose of work assessment is to improve or improve organizational performance through increasing the performance of HR organizations". Organizational performance is the result of individual performance and the HR team that exists in the organization, in other words, good or bad organizational performance is the result of HR performance. The benefits of assessing performance are:

a. As a basis for decision making.

b. Measuring the extent to which an employee can complete his work.

c. As a basis for evaluating the effectiveness of all activities.

d. As a basis for evaluating training programs and the effectiveness of work schedules.

e. As an indicator to determine the need for training for employees.

f. As a tool to increase employee motivation.

g. As a tool to see weaknesses or weaknesses and improve the ability of the next employee.

h. As determining criteria, selection, and placement.

i. To improve or develop employee skills.

j. The basis for improving or developing tasks.

The benefits of performance evaluation will be felt by both parties, namely leaders and employees, leaders through Performance Evaluation can communicate to subordinates about what the organization wants to achieve and subordinates through evaluation can find feedback to improve their performance in order to achieve a successful career.

\section{b. Talent}

One employee's talent or talent results from two conditions, namely; brought from the beginning to join the company and formed during the Human Resources development program at the company.

The study of talent develops today as a human resource process that is integrated with company goals that will affect the performance of the employee itself. According to Dessler (2013:130) "Talent as goal-oriented and integrated processes of planning, recruiting, developing and managing employees" talent as a goal-oriented and integrated process in planning, withdrawal, developing, managing and providing employee compensation. Talent also means how the company manages its resources starting from the process of recruitment, employee placement, performance appraisal, training, and career development until employees leave the company so that ultimately the company's goals can be achieved.

\section{c. Performance}

The measure of organizational performance is the extent to which the vision, mission, and goals of the organization are achieved, the process of achieving 
Proceeding ICOGISS 2019

Page: 529-535 ISBN: 978-602-6 988-75-1

Web Jurnal Online: jurnal.unmuhjember.ac.id

By: Asep Nurwanda; Regi Refian Garis

Analysis Of Performance Appraisal, Talent, Performance Of State Civil Apparatus In Realizing Good Government Governance (Analysis Study On Bkdd Of Ciamis Regency)

organizational goals is now better known as performance. Performance means that managers ensure that employees' activities and output are congruent with the organization's goals.

Noe. et al. (2008:342). Performance is a means through which managers ensure that employee activities and output are the same as those of the organization. Whereas Dessler (2013:312), We assume Performance is a uniquely goal-oriented and continuous way to appraise and manage employees' performance. It is the "continuous process of identifying, measuring, and developing the performance of individuals and teams and aligning their performance with the organization's goals.

We assume Performance is a unique, goal-oriented and continuous way to assess and manage employee performance. This is "a continuous process of identifying, measuring, and developing individual and team performance and harmonizing their performance with organizational goals. It is clear that performance management is a continuous process of identifying, measuring, and developing individual and team performance by managers by aligning their performance with organizational goals In another book (Dessler 2008: 290) states that "Performance processes that consolidate goal setting, performance appraisal, and development into a single, comment system, the aim of which is that the employee's performance is supporting the company strategic aims. "Performance is a process that consolidates goal setting, performance appraisal, and development into a single system whose purpose is to ensure that employee performance supports the company's strategic goals. Managers or personnel must assess employees based on standards. Certainly what can be measured and the goals of employees with performance standards must be reasonable in terms of achieving the company's strategic goals.

\section{RESEARCH METHODS}

The research method used is a qualitative method, qualitative method according to Sugiono (2012: 9) is a research method based on postpositive philosophy, used to examine the condition of natural objects, (as opposed to experiments) where researchers are key instruments, collection techniques data is done in triangulation (combined), data analysis is inductive/qualitative, and the results of qualitative research emphasize the meaning rather than generalization. The postpositivist approach views social reality as something holistic/intact, complex, dynamic, full of which, and the relationship of symptoms is interactive (reciprocal). In qualitative research, it is necessary to emphasize the importance of closeness to people and research situations, so that researchers gain a clear understanding of reality and real-life conditions.

\section{RESULTS AND DISCUSSION}

The role of BKDD as the spearhead in carrying out ASN performance appraisal is not optimal, when viewed from the concept of performance evaluation so far that has not been able to realize a process of evaluating employee performance compared to the standard set, it has not been able to realize a process of how well an employee performs 
his job, has not been able to realize a process of assessing whether an employee does his job in accordance with his duties and responsibilities, has not been able to realize a process of assessing whether the employee or organization complies with the performance standards or objectives set first.

The role of BKDD is also not optimal when looking at the conditions that a performance assessment must meet three conditions; Input (potential), 2). Process (implementation), and 3). Output (results). In terms of input or potential conditions have not been established, agreed upon and known factors that will be assessed beforehand by employees who will be assessed because the work target or work schedule is unclear. In terms of the process (implementation), there has not been consultation with as many individuals and groups as possible to be assessed to ensure that all aspects of the performance appraisal system can be connected as a whole so that it can run well. In terms of output (results), results are still subjective, benefits, impacts, risks, and follow-up assessments are unclear. The results of the assessment have not succeeded in improving the quality of work, work motivation, work ethic and job satisfaction of the ASN, and have not reflected on improving government performance.

ASN performance appraisal is still carried out on ASN work behavior not yet on work results compared to predetermined standards or previously set plans. In 2014 the plan will be applied to the performance assessment system / ASN work performance based on Government Regulation /PP No. 46 In 2011 concerning the Assessment of Civil Servants' Work Performance, namely on the $60 \%$ ASN work target and $40 \%$ ASN work behavior. This is an expectation that the optimal ASN performance assessment is carried out which results can be used in the interest of improving the performance of the ASN and the realization of good governance. Employee Work Objectives (SKP) are work plans and targets to be achieved by an ASN within one year as a description of the goals and programs of government agencies. The work behavior is any behavior, attitude or action taken by the ASN or does not do something that should be done in accordance with the provisions of the legislation.

The talent of Civil Servants is a process that is oriented towards integrated government goals in the planning, withdrawal, development, management, and provision of employee compensation by national or regional staffing agencies. The aim of the government is the objective of the administration of the State of Indonesia, namely to form an Indonesian state government that protects the entire Indonesian nation and the entire Indonesian bloodshed and to promote public welfare, educate the nation's life and participate in carrying out world order based on freedom, eternal peace and social justice. Implementation of talent To determine the suitability between the personality and competencies that CASN / ASN has with the work that will be done so that they can plan their career (Employee career plan). The instrument used is an instrument that can reveal both the characteristics and competencies of each employee or prospective employee that are tailored to the job/position to be performed.

The State Civil Service Agency as the organizer of the Central Civil Servants and the Regional Personnel Agency plans, develops the quality of Civil Servants' resources 
Page: 529-535 ISBN: 978-602-6 988-75-1

Web Jurnal Online: jurnal.unmuhjember.ac.id

By: Asep Nurwanda; Regi Refian Garis

Analysis Of Performance Appraisal, Talent, Performance Of State Civil Apparatus In Realizing Good Government Governance (Analysis Study On Bkdd Of Ciamis Regency)

and personnel administration, supervises and controls, organizes and maintains personal information, formulates the policies of Civil Servants welfare. ASN currently still has a number of fundamental weaknesses, including a). more highlighting the administrative side than the side in particular modern resources, b). programs are more centralized and lack innovation, c). lack of efficiency and effectiveness in achieving organizational goals from each agency both at the central and regional levels, d). has not yet accommodated well the classification of positions and competency standards so that it negatively affects the achievement of organizational and individual performance, e). appointments in positions that are not based on the results of performance appraisal so that real employee competencies cannot be obtained, in the system $\mathrm{f}$ ). education and training have not yet been part of the ASN career development system.

\section{CONCLUSION}

From the results of the above research, the researchers concluded that the implementation of Performance Appraisal, Talent of Civil Servants and Performance at BKDD in Ciamis Regency had not been able to realize Good Government Governance. This can be seen from the role of Civil Servants in implementing public services who still place themselves as bureaucrats, not as public servants. 
Proceeding ICOGISS 2019

Page: 529-535 ISBN: 978-602-6 988-75-1

Web Jurnal Online: jurnal.unmuhjember.ac.id

By: Asep Nurwanda; Regi Refian Garis

Analysis Of Performance Appraisal, Talent, Performance Of State Civil Apparatus In Realizing Good Government Governance (Analysis Study On Bkdd Of Ciamis Regency)

\section{REFERENCES}

Cubbingham, I. 2007. Talent: Making it real. Development and Learning in Organizations, 21(2):4-6.

Dharma, Surya. 2005. Kinerja. Jakarta: Pustaka Pelajar.

Dessler, Gary. 2008. Human Resource. Eleventh Edition. England: Pearson Eduation, Inc.

Lewis, Robert E. Talent: A critical review Human Resource. Human Resource Review 16 (2006) 139-154; www.sciencedrirect.com

Lewis, Robert E. 2006. Human Resource Review 16: 139-154.

Mangkunegara, A. Anwar Prabu. 2000. Sumber Daya Manusia. Bandung: PT Remaja Rosdakarya.

Noe, Raymond A., et.al. 2008. Human Resource: Gaining A Competitve Advantage. New York: McGraw-Hill Company.

Permana, Nina Insania K. dkk. 2011. Talent Implementation: Belajar dari Perusahanperusahaan terkemuka. Jakarta Pusat: PT. Mitrakerja Indonesia.

Rivai, Veithzal et al. (2011). Performance Appraisal. (Edisi Kedua) Jakarta: Raja Grafindo Persada.

Schiemann, Williams A. 2009 Reinveting Talent: How to Maximize in the New Marketplace. Penerjemah Setyo Utomo. Jakarta: PPM.

Sugiyono. 2012 Metode Penelitian Kuantitatif Kualitatif dan R\&D. Jakarta: Alfabeta. 